\title{
ECONOMIC IMPORTANCE AND MEDICINAL STRENGTH OF VIDANGA (EMBELIA RIBES) : AN ENDANGERED MEDICINAL PLANT OF WESTERN GHATS OF INDIA
}

\author{
Raviraja Shetty G. \\ Dept. of Plantation, Spices, Medicinal \& Aromatic Crops \\ College of Horticulture, Mudigere, UAHS, Shivamogga, Karnataka
}

Received: 24.04.2021

Revised: 05.05.2021

Accepted: 16.05.2021

\begin{abstract}
Embelia ribes Burm f. a medicinal woody climber belongs to the Myrsinaceae family. It is also commonly known as false black pepper or vidanga. E. ribes is one of the 32 medicinal plant species identified by the Medicinal Board, Govt. of India, New Delhi, as being important for large-scale cultivation because of its commercial use. It is an endangered medicinal plant valued for its digestive, thermogenic, carminative, depurative, anthelmintic and laxative property since time immemorial. It is also used in the treatment of tumours, asthma, bronchitis, diabetes, heart related problems, nerval disorders, cancerous tumors and liver disorders. E. ribes contain quinine derivative Embelin which has various pharmacological and medicinal properties. It helps to bring a medicinal plants revolution in our country good health and prosperity to people.
\end{abstract}

Keywords: Endangered, western Ghats, vidanga, medicinal property and conservation.

\section{INTRODUCTION}

The Western Ghats in India is one of the most threatened biodiversity hot spots of the world. Among the 600 plant species considered to be rare or threatened in the flora of the peninsular India, about 90 per cent species are in the Western Ghats. More than 63 per cent of the plant species of low and medium elevation evergreen forests are endemic (Ramesh et al., 1991). A greater fraction of these threatened species are medicinal plants. About 146 species are listed from Karnataka alone. Gowda et al. (2002) studied the habitats of Western Ghats and have revealed that, most of the eastern and western transition zones host a variety of RET species. Embelia ribes Burm $\mathrm{f}$. is one such species. According to IUCN (International Union for Conservation of Nature and Natural Resources), Switzerland. Embelia ribes commonly known as False Black Pepper, White-flowered Embelia, Vidanga, Vaividang, or Vai Vidang(MMPD, 2009) is a species in the Primulaceae. It was originally described by Nicolaas Laurens Burman in his 1768 publication, Flora Indica
(IOPI). It is one of the 32 medicinal plant species identified by the Medicinal Board, Govt. of India, New Delhi, as being important for large-scale cultivation because of its commercial use

\section{DISTRIBUTION}

It is mainly distributed in warmer regions of northern and southern hemisphere. Most of the genera and species are tropical. Genus Embelia, represented by more than 100 species, is distributed in Tropical Asia, Africa and Australia and Pacific islands. Species of Embelia like E. ribes and $E$. basaal are known for their medicinal use since thousands of years in parts of Southeast Asia. E. ribes is an Indo Malayan species, distributed in India, Sri Lanka, Singapore, Malaysia and S. China. It is sparsely distributed in the evergreen to moist deciduous forests of Arunachal Pradesh, Assam, Maharashtra, Andhra Pradesh, Karnataka, Kerala and Tamil Nadu and is now confined to the informally protected 'sacred groves' and restricted to a few remnant forest pockets and MPCAs (Medicinal Plant Conservation

*Corresponding author: rrshetty2059@gmail.com 
Areas) that Forest Department has established. Within India, it is found throughout up to an altitude of $1750 \mathrm{~m}$ amsl in these regions. It is 'Vulnerable- VU' in Karnataka and Tamil Nadu, 'Near Threatened - NT' in Arunachal Pradesh and Kerala and 'Data Deficient -DD' in Assam, Meghalaya, Sikkim and Maharashtra (CAMP, 2001). In Karnataka, E. ribes is distributed in evergreen forests. In northern parts of Western Ghats, E. ribes is distributed on edges of disturbed evergreen and semi evergreen forests (Mhaskar et al., 2011). Recently Hareesh et al. (2009) reported that in humid tropics of the central Western Ghats, only 8 individuals out of 24 identified in a $1 \mathrm{~km}$ transect bear fruits. Although size class distribution of lianas suggested a near 'reserve J' pattern, the regeneration was restricted to mildly disturbed spots.

\section{BOTANICAL DESCRIPTION}

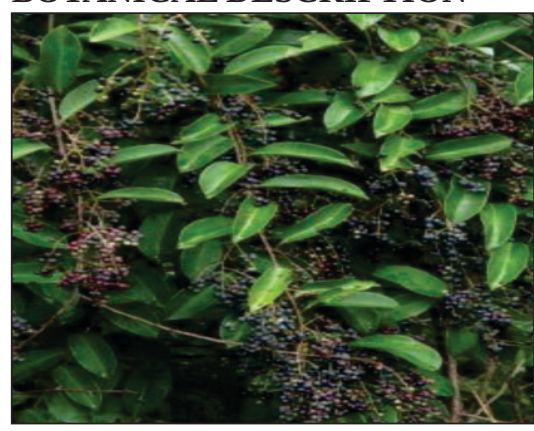

Flowers

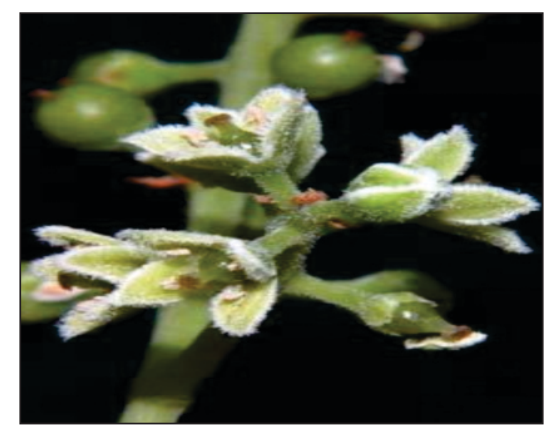

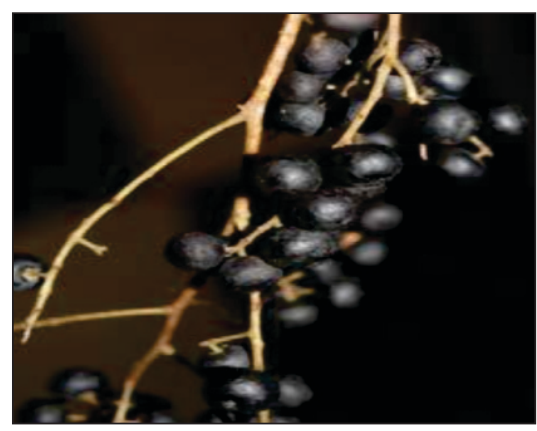

Fruits
It is a dioecious woody climber with lenticellular bark with whitish grey stem and long, slender, flexible, terete branches. The roots are brownish grey with hairy reddish rootlets; leaves are simple, alternate, elliptic-lanceolate, coriaceous, gland-dotted, entire, shiny above and silvery beneath; flowers are small, white or greenish borne in panicles; fruits are globular berries, small like that of a pepper, wrinkled or warty, dull red to black, 1- or 2-seeded; seeds are globose, hollowed at the base, white-spotted. ( Kirtikar KR et al.1993)

\section{CHEMICAL CONSTITUENTS \\ Major constituents: Embelin}

Other constituents: Vilangin, Quercitol, Tannins, Volatile Oil

\section{FLORALBIOLOGY}

Flowers are small, white or greenish borne in panicles. Petiole is $1.0 \mathrm{~cm}$, midrib is prominent, racemes type of inflorescences shown \& flower buds are small globules greenish yellow before maturing, after maturing in sunshine the sepal from calyx and the Petiole is greenish yellow \& petal from corolla is whitish pink in which one of the corolla is bigger than 4 number. Stamens are dark yellowish-pink arranged radially which is cone shape and spiny structure is inclined \& broad structure shows divided into two anthers as projected tapering styloid which is attached dorsifixed stamens with the filament attached at $45^{\circ}$ angle The sepals shows attached to the petiole with a marking above the neck at $45^{\circ}$ angle shows a shape of hand as 3 fingers as dentate and short toes. (Syed Asadulla et al .2012)

PARTS USED: Berries (fruit), leaves, root bark.

\section{MEDICINAL USES}

Embelia ribes is also one among the top 20 ayurvedic drugs of the country. It is effective used in the treatment of ascariasis Sore throat, abdominal, inflammatory and mental disorders, constipation, headache, flatulence, indigestion, jaundice, snake bite, skin diseases, leprosy, nervous debility, dyspepsia, colic, tumors, asthma, and general debility.( Shah CS et al.1961)

Embelia root bark is acrid, astringent and has anthelmintic, antifertility, anthioestrigenic, carminative, digestive, laxative, soothing, stimulant, stomachic, and thermogenic properties. It is effective against intestinal parasites and intestinal worms. It is used in abdominal disorders, fungal skin infections, flatulence, constipation indigestion, headache, hemorrhoids, lung diseases, obesity, piles, pueumonia, mouth ulcers, toothache and sore throat. Its decoction is useful in insanity and heart diseases. The root of $E$. ribes is boiled in water and the decoction is effective against chest pains. Besides, paste of powdered leaves, mixed with honey is consumed to treat ulcers of mouth (Sharma GK et al.1997). Roots are ground with lime juice and taken orally with honey against cough. The roots and leaves are astringent; thermogenic and stomachic .Leaves are astringent, thermogenic, demulcent and depurative in nature. It is useful in skin diseases and leprosy. Fruits are 
acrid, astringent, anthelmintic, bitter, brain tonic, caraminative, contraceptive, diuretic, febrifuge, laxative, stimulant, and thermogenic.

\section{TRADITIONAL USES}

Embelia ribes has numerous traditional medicinal uses. The main preparations employing the drug are Vidangaadi chruna, Vidangarishta, sarvajwara louha, Agnitundi vati, Yograja gugglu Kaishor gugglu, Chandraprabha Vati and Vidanga taila(Balakrishna Gowda, et al.2010). In olden days, dried fruits were considered for anthelmintic, astringent, carminative and used as an alternative and stimulant and usually administered as powder along with milk, followed by a purgative. It was also effective for the treatment of ascariasis better than Santonin and as good as Oil of Chenopodium . This product provides all the Rasayan benefits(Charak Samhita, 1998).The persons using Rasayan treatment in early ages lived very long life unaffected by old age, debility, illness untimely death.

\section{CULTIVATION PRACTICES:}

\section{SOILAND CLIMATE}

The plant can be grown in variety of soils including light black cotton soil, sandy/rocky in different agro-climatic conditions in tropical regions up to 800-1500 m. altitude.

\section{CLIMATE}

Earlier attempts to plant E. ribes in areas outside the natural range were attempted by TBGRI (Tropical Botanical Garden Research Institute), Thiruvananthapuram, IFGTB (Institute of Forest Genetics and Tree Breeding), Coimbatore, UAS (University of Agricultural Sciences), and FRLHT (Foundation for Revitalization of local Health Tradition), Bangalore. Personal visits to these sites indicate that except in TBGRI which is in natural zone of E. ribes , all other attempts did not yield positive results. Only one surviving plant exists in FRLHT while the Botanical Garden of UAS Bangalore contains E. tsjeriamkottam and not E. ribes. In FRLHT, though flowering was observed after 4 - 5 years of planting, but fruiting and seed setting was not observed although plant contains bisexual flowers.

\section{PROPAGATION}

Natural regeneration of $E$. ribes is poor due to overharvesting and exploitation, more fragmented populations resulting in inbreeding, development of abortive embryos, and the slow germination of fertile seeds that are small in size. On the other hand, artificial regeneration of this species is difficult due to its poor seed viability, low rate of germination, and poor rooting from stem cuttings.

Habitat loss, Jhum cultivation, forest fire and agriculture expansions are also some factors for its decrease in population. The regeneration from seedling of this plant is very poor3. The embryos of E.ribes are very small when present and most of the seeds are abortive. For the survival and growth of E.ribes specific habitat conditions are essential. Regeneration of E.ribes is very poor and slow. The ideal time for seed collection is from June to August. Mature seeds of E. ribes are purple to black unlike red colored seeds of E. basaal. Propagation can be achieved through seed germination and through stem cuttings.

\section{BY SEEDS}

Matured and ripened fruits are packed in polythene covers and placed under the artificial light source for $8 \mathrm{~h}$ per day. The cycle is continued for a period of 4-5 days. Pre sowing treatment of (10 per cent) H2SO4 for 10 min + GA3 (4000 ppm) is the best treatment for Embelia ribes. By this method,40 per cent seed germination can be achieved successfully. Sand media are sufficient to achieve the seed germination. Sand bed with at least $9 \mathrm{~cm}$ thickness prepared in large tray is sufficient for raising seedlings under nursery conditions. Seeds are sown in a row inside the handmade furrows. Uniform and thin layer of sand should be spread over the seeds. Immediate watering should be done. Seed germination starts after 50 days of sowing with 40 per cent germination.

\section{BY STEM CUTTING}

Pencil sized stem cuttings of 1.0-1.5 cm thickness bearing 3 nodes are planted $3 \mathrm{~cm}$ deep in polybags and kept in shade. Cuttings are treated with two types of root regulators such as Indole Butyric Acid (IBA) (200ppm) and commercial quick root solution before planting. Post-Monsoon season is the best time for collection of stem cuttings.

Pre treated stem cuttings are placed in root trainers and transferred to poly chambers. Rooting media is prepared from sand, coir pith and perlite. Microclimate with ambient condition is created inside the micro-poly chambers. By this method nearly 10 per cent of the stem cuttings sprout immediately. The rooting commences only after 35-40 days and within 3 weeks one or two axillary buds above the leaf scars develop and grow into branches. After the formation of healthy root system, it is ready for transplanting. semi hardwood cuttings with two or three leaves, treated with IBA in $3000 \mathrm{mg} / \mathrm{l}$ concentration in season I(January - April) appeared to be a successful method for vegetative propagation (100\% rooting) for producing sufficient number of propagules of this species(Saumya M.T et al. 2014).

\section{MANURE/FERTILIZER}

Compost/Vermi compost, organic manure is preferred.

\section{IRRIGATION}

The plantation can be irrigated usually at an interval of 15 days. 


\section{HARVESTING/POST HARVESTING OPERATION}

Harvesting is done after two years. Generally, fruiting starts in August-September after 2 years of transplantation and fruit ripes during November to January. The fruits are collected, dried in shade and stored in clean porous Jutebags. The fruits are collected manually and the plant is allowed to grow further.

\section{YIELD}

The dry fruits of about 25-q/h hectare can be collected.

\section{REFERENCES}

1. Anand Kumar BH, Sachidanand YN. Treatment of Acne Vulgaris with new polyherbal formulations, Clarina Cream and Purim Tablets. Indian J Dermatol 2001; 46(3): 138-141.

2. Balakrishna Gowda, Chandrika K, Prasanna KT, Kirana VC. AFLP authentication of Embelia ribes Burm.F and Embelia tsjeriam cottama. DC. Int J Sci Nat. 2010; 1(1): 58-60.

3. Bheemasankara Rao C, Venkateswara Rao V, Venkateswarlu V. Analytical application of embelin. Fresen J Anal Chem. 1960; 175(2): 114-117.

4. Bheemasankara Rao C., Venkateswara Rao V., Venkateswarlu V. Analytical application of embelin. Fresen J Anal Chem. 1962; 185(3): 216-218.

5. Central Research Station, Dr. Punjab Rao Deshmukh, Krishi Vidyapeeth, Akola (Maharashtra).

6. Charak Samhita, P V Sharma. 4th Edition, 1998 Chaukhambha Orientalia Varanasi, Section 6 Chikitsasthanam, Chapter 1,Qtr 1, pp 12, Shloka 7880.

7. Gupta R., Sharma A.K., Mahesh C., Gupta R.S. Antioxidant activity and protection of pancreatic $\beta$ cells by embelin in streptozotocin induced diabetes. $J$ Diabetes. 2012;248-56.

8. Harish Chander and Ahmed S.M. Laboratory evaluation of natural embelin a grain protectant against some insect pests of wheat in storage. $J$ Stored Prod Res. 1987; 23(1): 41-46.

9. Hareesh T.S., Hegde V.D., Gunaga S., Gunaga R.P. and Vasudeva R. 2009. Occurrence and regeneration status of Embelia ribes Burm. F.: an endangered and medicinally important liana of central western ghats. Journal of Non-Timber Forest Products. 16(1): 5-10.

10. International Organization for Plant Information (IOPI). "Plant Name Search Results" (HTML). International Plant Names Index. Retrieved13 October 2009.
11. Kalaiselvi D. and Renuka R. Plant substances as battery cathodes: Zinc-embelin organic secondary battery. J Appl Electrochem. 1999; 29(2): 797-803.

12. Kirtikar K.R. and Basu B.D. Indian Medicinal Plants. Dehradun, India, 1993.

13. Krishnaswamy and Purushothaman: Antifertility properties of Embelia ribes. Ind. J. Exp. Biol. 1980; 1359-1360.

14. Kole P.L., Jadhav H.R., Thakurdesai P., Nagappa A.N. Cosmetics potential of herbal extracts. Nat Prod Rad. 2005; 4(4): 315-321.

15. Kumara Swamy H.M., Krishna V., Shankarmurthy K., Abdul Rahiman B., Mankani K.L., Mahadeven K.M., Harish B.G. and Raja Naika H. 2007. Wound healing activity of embelin isolated from the ethanol extract of leaves of Embelia ribes Burm. J. Ethnopharmacol. 109 (3): 529-534.

16. Mhaskar M., Joshi S., Chavan B., Joglekar A., Barve N. and Patwardhan A. 2011. Status of Embelia ribes Burm f. (Vidanga), an important medicinal species of commerce from northern Western Ghats of India. Current Science. 100(4): 547552.

17. Prakash Paranjpe and Kulkarni P.H.. Comparative efficacy of four Ayurvedic formulations in the treatment of acne vulgaris: a double-blind randomized placebo, controlled clinical evaluation. $J$ Ethnopharmacol. 1995; 49(3): 127-132.

18. Radhakrishnan N., Kavitha V., Raja S.T.K., Gnanamani A., Mandal A.B. Embelin-A natural potential cosmetic agent. J Appl Cosmetol. 2011; 29(2): 99-107.

19. Renuka R, Rajasekaran S, Ganga R. Electrochemically synthesized polymer of the plant substance embelin (2, 5-dihydroxy -3-undecyl, 1, 4benzoquinone). Appl Biochem Biotechnol. 2001; 96(1-3): 83-92.

20. Samatha S., Vasudevan T.N. Natural hair dyes. $J$ Scientific \& Industrial Res. 1996; 55(11): 885-887.

21. Saumya M.T., Surendran T. and Hrideek T.K. ,2014. Research Journal of Agriculture and Forestry Sciences. ISSN 2320-6063 Vol. 2(2), 8-12).

22. Shah C.S. and Khanna P.N.. 1961. Pharmacognostic comparison of Embelia ribes Burm. and E. robusta C.B. Clarke fruits. The Indian Journal of Pharmacy 23(10): 275-276.

23. Sharma G.K.. 1997. Ethnomedicinal flora: Ayurvedic system of medicine in a remote part of the 
Indo-Tibetan Himalayas. Journal of the Tennessee Academy of Science. 72(3-4): 53-55.

24. Syed Asadulla, Ramandang and Rajasekharan. 2012 taxonomy \& flower stages in embelia ribes burm $\mathrm{f}$, International Journal of Research In Pharmacy and Chemistry, 2(2) : 2231-2781.
25. "Sorting Embelianames". Multilingual Multiscript Plant Database. The University of Melbourne. Retrieved 2009-08-11.

26. www.hcms.org.in/product. 